\section{Circulating immune complexes in infants fed on cow's milk}

Circularivi antigen-antibody (AgAb) complexes are capable of damaging various tissues, for example, renal glomeruli, vesscls and joints'. In addition, immune complexes (IC) can interfere with cellular immunity and, to some extent, decrease the immunc response ${ }^{2+4}$. We report here that all infants fed on cow's milk have circulating complexes containing bovine proteins as antigens and IgG antibodies of maternal origin. These data raise questions as to the possible involvement of such complexes in various disorders, the intestinal resorption of macromolecules, and the development of antibodies against food antigens.

IC were detected by their ability to inhibit the agglutinating activity of rheumatoid factor (RF) or purified human $\mathrm{Clq}$, a constituent of the first factor of complement. towards particles coated with human $\operatorname{IgG} \mathrm{i}^{\circ}$. As $\mathrm{RF}$. we used the suitably diluted $(1 / 200)$ serum of a patient with rheumatoid arthritis.

The tests were performed on blood samples from 46 neonates. on their cord sera as well as on serum samples collected 6 d after birth. While their cord scra werc negative, 24 had. on the sixth day, factors inhibiting RF and Clg at serum dilutions ranging from $1 / 2$ to $1 / 8$. Of these 24 , only one was breast-fed. The others received either cow's milk alone $(N=11)$ or as a supplement to breast-fecding $(N=12)$. Of the 22 infants without IC, 21 were breast-fed and one received mixed food.

Large excess of antigen is known to reduce the inhibitory activity of immune complexes". Hence. the addition of bovine milk proteins to these sera with inhibitory activity should decrease the reaction with RF or C.Iq. if the antigen of the immune complexes came from the milk. A 1 "., solution of the milk powder which was used for feeding the babies (Guigolac) was prepared in saline. One volume of this solution. which was itself devoid of any agglutinating or inhibitory activity. was incubated for $30 \mathrm{~min}$ at $37^{\circ} \mathrm{C}$ and overnight at $4^{\circ} \mathrm{C}$ with one volume of serum from each of two infants which inhibited $R F$ and $C l q$ up to $1 / 8$ dilution. After addition of bovine milk, the sera completely lost their inhibitory activity. Controls were performed on two cord sera containing immune complexes (inhibition titres $1 / 8$ toward $R F$ and $C$ lq) as a result of neonatal infections ${ }^{6}$. and allowing for the effect of dilutions on the inhibition titres. no significant changes were observed after addition of bovine milk to these sera. By showing that the immune complexes contained hovine milk proteins as antigen, we confirmed that the neonatal intestine is permeable to macromolecules ${ }^{i-9}$.

That the antibody involved in the complexes was Ig. was suspected by exclusion of the other main Ig classes. RF is known to be poorly inhibited by polymerised lgM. and polymerised Ig.A does not inhibit the agglutinating activity of $C^{\prime} 1 q^{5}$. As all positive sera reacted with both RF and Ciq, it was unlikely that these Ig were involved in the immune complexes.

In the 6-d-old infants, most IgG antibodies are of maternal origin. Hence, the anti-milk antibody was presumably acquired through the placenta from the mother. If this hypothesis were true. the addition of mothers' sera to infants' sera should increase the proportion of antibody to antigen, and thus the size and inhibitory activity of the complexes'. As sources of maternal immunoglobulins. we used cord sera. One volume of infant's serum was mixed with one volume of the serum from its own cord blood. and incubated at $37 \mathrm{C}$ for $30 \mathrm{~min}$. and then at $4{ }^{\circ} \mathrm{C}$. overnight. This experiment was performed on sera from 4.3 infants whose cord sera were devoid of immune complexes. The addition of cord serum caused a significant increase of the inhibitory activity (at least two dilution titres) in 17 sera. Of these. 13 came from infants receiving cow's milk or mixed feeding $(N=21)$. Of the 26 sera in which no increase of the inhibitory activity was observed. 18 were from breast-fed infants $(N=22)$. The correlation between the antigen-antibody reactions and the milk source was highly significant $\left(x^{2}=7.6 ; 0.01>P>0.001\right)$.

The existence of antibody against bovine milk in cord blood was confirmed by counter-electrophoresis using eight dilutions of Guigolac, from 0.08 to $10 \mathrm{mg} \mathrm{m}^{-1}$. The occurrence of IgG antihody against bovine casein in cord blood had already been reported ${ }^{10}$.

To check the frequency of anti-bovine milk antibody, we collected serum from 50 healthy members of our staff. All these sera gave a precipitin line against at least one dilution of Guigolac as did a commercial preparation of $\gamma$-globulins ( $165 \mathrm{mg} \mathrm{m}^{-1}$ ) (Institut Mérieux). To check that the precipitin line was really the result of an antigenantihody reaction. $F\left(a b^{\prime}\right)$, fragments were prepared from $\gamma$-globulins by pepsin digestion ${ }^{11}$. A solution of $10 \mathrm{mg} \mathrm{ml}^{-1}$ $F\left(a b^{\prime}\right)$ : fragments also gave a clear precipitin line.

Antibody activity against bovine milk has been detected in IgA from mother's milk ${ }^{12,13}$. So. mixed feeding should prevent the resurption of cow's milk proteins. However. we did not find less circulating immune complexes in infants on mixed feeding.

Various disorders have been attributed to bottle feeding such as allergy and recurrent infections ${ }^{14.15}$. By their interference with the immune response. immune complexes could be involved in the development of these disorders. A possible long-term consequence of the occurrence of circulating immune complexes during infancy is arteriosclerosis. In animals. serum sickness accelerates its development ${ }^{16-18}$. and coronary lesions are more common in people who were fed on cow's milk than in those who were breast-fed ${ }^{19.20}$. By damaging the arterial endothelium. the immune complexes could facilitate the deposition of lipids and the formation of the atheroma plate ${ }^{21}$.

We thank Dr A. Leek for criticism and Mrs C. PeetersVandermaelen for technical assistance. This work was supported by the Fonds de la Recherche Scientifique Médicale. Brussels, and by the Cancer Research Fund of the Caisse Générale d'Epargne et de Retraite. Brussels.

\section{Delire \\ C. L. Cambiaso \\ P. L. MASSON}

Unit of Experimental Medicine,

International Institute of Cellular and Molecular Pathology,

Université Catholique de Louvain,

7.5, avenue Hippocrate,

B-I200 Brussels, Belgium

Received 19 December 1977: accepted 20 February 1978.

1. Dixon. F. J. Harrey, Loc. . 58. 21-52(1963). Sjögren. H. O.. Heillström. Hansal.S. C. \& Hellström, K.-E. Proc. nain. Acad.

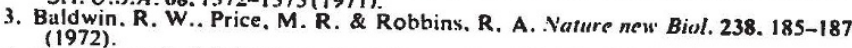

4. Kontiainen.S. \& Mitchison. N. A. Immumelegy, 28. 523-533(1975).

Lurhuma, A. Z., Cambiaso. C. L... Masson. P. L. \& Heremans. J. F. Clin. exp Immun. 25. 212-226(1976).

. Delire. M. F.. Leciercy. C. L.. Cambiaso. C. L.. Masson. P. L. \& Malherbe A.

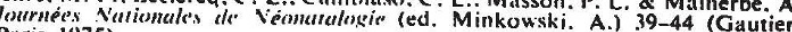

7. Anderson. A. F.. Sihloss. O. M. \& Myers. C. Pres. Soc. exp. Biel. Michl. 23. $180-182(1925)$

8. Lippird. v. W.. Schloss. O. M.. Johnson. P. A. Am. J. đis. Chilt, 51. 562-574

9. Gruskay. F. L. \& Cooke. R. F. Pedlicuries 16. 763-769(1955).

10. Hunter, A.. Feinstein. A. \& Coombs. R. R. A. lmmmmefleg. 15. 381-388 (1968). 11. Heinler R. Sclinoll. S. S. \& Primack. A. Bisechemistri 6. 127-i34 (1967)

13. McClelland. D. B. L. \& McDunald. T. T. Lamertii. 1251-1252(1976).

Hanson. L. A.. Ahlstedl, S. Cartsson, B. \& Fïlström. S. P. Int. Archs Allergy (Ippl. Immmin. $54.457-462(1977)$.

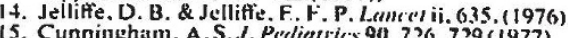
16. Minick. C. R.. Murphy. G. E. \& Camphell. W. G.. Jr J. exp. A/ed. 124. 635-652

17. Lamberson.H. V. \& Frit. K. E. Archs Pall 98.9.16(1974).

19. Oshorn. G. R. (coll. Inurn. C....K.S. (eds Lenegre. M. J.. Stebat. L. \& Renais, J.193-1.39(1908)

20. Turner. R. W. D. Lancet ji. 693-694(1976)

21. Ross. R. \& Cilumser. J. A. I. Engl. J. I/rt. 295. 369-377 \& 420-425 (1976) 